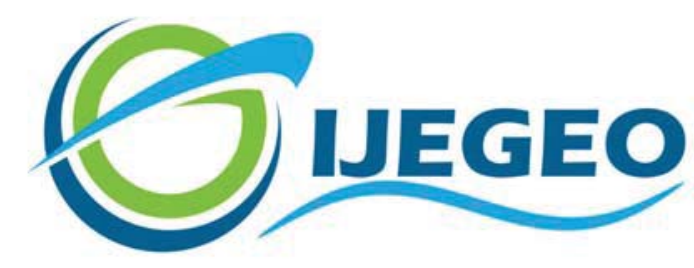

International Journal of Environment and Geoinformatics (IJEGEO) is an international, multidisciplinary, peer reviewed, open access journal.

\title{
The separation characteristics of an isopropyl alcohol/water azeotrope using evapomeation and temperature-difference controlling evapomeation methods with PVA/NaY membranes
}

\section{Fatma KURŞUN BAYSAK}

\author{
Chief in Editor \\ Prof. Dr. Cem Gazioğlu \\ Co-Editors \\ Prof. Dr. Dursun Zafer Şeker, Prof. Dr. Şinasi Kaya, \\ Prof. Dr. Ayşegül Tanık and Assist. Prof. Dr. Volkan Demir
}

Editorial Committee (September 2021)

Assoc. Prof. Dr. Abdullah Aksu (TR), Assit. Prof. Dr. Uğur Algancı (TR), Prof. Dr. Bedri Alpar (TR), Assoc. Prof. Dr. Aslı Aslan (US), Prof. Dr. Levent Bat (TR), Prof. Dr. Paul Bates (UK), İrşad Bayırhan (TR), Prof. Dr. Bülent Bayram (TR), Prof. Dr. Luis M. Botana (ES), Prof. Dr. Nuray Çağlar (TR), Prof. Dr. Sukanta Dash (IN), Dr. Soofia T. Elias (UK), Prof. Dr. A. Evren Erginal (TR), Assoc. Prof. Dr. Cüneyt Erenoğlu (TR), Dr. Dieter Fritsch (DE), Prof. Dr. Çiğdem Göksel (TR), Prof.Dr. Lena Halounova (CZ), Prof. Dr. Manik Kalubarme (IN), Dr. Hakan Kaya (TR), Assist. Prof. Dr. Serkan Kükrer (TR), Assoc. Prof. Dr. Maged Marghany (MY), Prof. Dr. Michael Meadows (ZA), Prof. Dr. Nebiye Musaoğlu (TR), Prof. Dr. Masafumi Nakagawa (JP), Prof. Dr. Hasan Özdemir (TR), Prof. Dr. Chryssy Potsiou (GR), Prof. Dr. Erol Sarı (TR), Prof. Dr. Maria Paradiso (IT), Prof. Dr. Petros Patias (GR), Prof. Dr. Elif Sertel (TR), Prof. Dr. Nüket Sivri (TR), Prof. Dr. Füsun Balık Şanlı (TR), Prof. Dr. Uğur Şanlı (TR), Duygu Ülker (TR), Prof. Dr. Seyfettin Taş (TR), Assoc. Prof. Dr. Ömer Suat Taşkın (TR), Assist. Prof. Dr. Tuba Ünsal (TR), Dr. Manousos Valyrakis (UK), Dr. İnese Varna (LV), Dr. Petra Visser (NL), Prof. Dr. Selma Ünlü (TR), Assoc. Prof. Dr. Oral Yağcı (TR), Prof. Dr. Murat Yakar (TR), Assoc. Prof. Dr. İ. Noyan Yılmaz (AU); Assit. Prof. Dr. Sibel Zeki (TR) 


\title{
The separation characteristics of an isopropyl alcohol/water azeotrope using evapomeation and temperature-difference controlling evapomeation methods with PVA/NaY membranes
}

\author{
Fatma Kurşun Baysak \\ Department of Chemistry, Faculty of Arts and Sciences, Kırklareli University, 39100, Kırklareli, TURKEY
}

E-mail: fatma.kursun@klu.edu.tr

Received 15 Feb 2020 Accepted 22 Feb. 2021

How to cite: Baysak (2021). The separation characteristics of an isopropyl alcohol/water azeotrope using evapomeation and temperaturedifference controlling evapomeation methods with PVA/NaY membranes, International Journal of Environment and Geoinformatics (IJEGEO), 8(3): 344-349. doi.10.30897/ijegeo. 881056

\begin{abstract}
This study investigated the permeation and separation characteristics during the evapomeation and temperature-difference controlling evapomeation (TDEV) of an isopropyl alcohol/water (IPA/water) azeotrope through poly(vinyl alcohol)/NaY (PVA/NaY) membranes. The effects of the operational temperature and the feed concentration on the membrane separation factor and flux values were investigated for evapomeation and TDEV. The permeation and diffusion activation energies for an IPA/water mixture through a PVA/NaY membrane were calculated to be 23.69 and $41.61 \mathrm{~kJ} / \mathrm{mol}$, respectively. The results for the PVA and PVA/NaY membranes were supported by swelling behaviors. The best separation factor obtained was 2097.38 using the evapomeation method and 2483.75 using the TDEV method.
\end{abstract}

Keywords: Isopropy alcohol, Evapomeation, TDEV, Membrane

\section{Introduction}

IPA (isopropyl alcohol) is an important alcohol with a wide range of applications in cosmetics, perfumes, household chemicals, disinfectants, repellents, etc., in the pharmaceutical industries and in semiconductors due to its relatively high volatility and low toxicity. For industrial applications, IPA should generally be anhydrous, but IPA forms an azeotropic mixture with water (87.4\% IPA/water) (Kwon et al., 2018; Salehian and Chung, 2017). A list of membrane-based separation processes for azeotropic mixtures includes diffusion dialysis, reverse osmosis, nanofiltration, microfiltration, pervapour ation, evapomeation and TDEV (Dmitrenko et al., 2020).

Conventional separation methods other than pervapour ation, evapomation and TDEV methods have disadvantages such as the need for an additional step for the separation of the entrainer, the process control is not flexible, the application costs are high and they are not highly successful in separating very low concentration solutions and azeotropic mixtures (Asman aŞanli, 2006).

In pervapour ation, evapomeation and TDEV methods, the membrane is used as a barrier between the feed solution and the permeate vapour passing through the membrane. In the pervapour ation method, transport takes place in a three-step sequence: absorption into the membrane, diffusion through the membrane and desorption from the membrane to the vapour phase (Fan et al., 2003). Also with this method, since the membrane is in direct contact with the feed solution, there are disadvantages such as membrane swelling or shrinkage, which cause a decrease in the separation factor (Uragami, 2017).

In the evapomeation method, the feed solution is not in direct contact with the membrane, and only vapour is supplied to the membrane (Uragami, 2018). Thus, no phase change occurs from the feed solution to the permeation side, and the separation factor can be increased by pressurizing the feed vapour while the effects of swelling, concentration polarization and membrane fouling can be reduced. As the liquid mixtures evapor ate, interactions between molecules are significantly weakened, and so separation performance is significantly improved.

The TDEV method is based on keeping the temperature of the membrane zone and the temperature of the feed solution different (Uragami and Morikawa, 1989). The evapomeation and TDEV methods predominantly allow water to pass through the membrane to separate azeotropic mixtures. Therefore, these membranes must be water-selective, hydrophilic and water-resistant.

Until now, hydrophilic membranes like chitosan, poly (vinyl alcohol), polystyrene and alginic acid have been used by applying various modifications, such as crosslinking, graft copolymerization and blending (Ang et al., 2020). Known for its excellent membrane forming ability, environmentally friendly structure, low cost, low hardness and ease of modification, PVA has rather poor 
stability in aqueous solutions compared to other hydrophilic polymers (Bui et al., 2017; Kwon et al., 2018). In this way, it is worthwhile to improve the required mechanical properties and selective water permeability of PVA membranes by blending it with $\mathrm{NaY}$ zeolite.

In a previous study, $\mathrm{PVA} / \mathrm{NaY}$ blended membranes were prepared, and the pervapour ation performances of IPA/water mixtures were examined (Kurşun, 2020). In this study, the performance of evapomeation and TDEV methods for IPA/water mixtures were investigated using PVA/NaY blended membranes. The effects of operational temperature and feed concentrations on the membrane separation factor and flux were carried out for evapomeation and TDEV. The permeation and diffusion activation energies for IPA/water mixture through the PVA/NaY membrane were calculated. The results for PVA and PVA/NaY membranes were supported by swelling behaviours.

\section{Materials and Methods}

$\mathrm{NaY}$ zeolite (with an average particle size of $\sim 2 \mu \mathrm{m}$ and a linear formula of $\left.\mathrm{Na}_{86}\left[\left(\mathrm{AlO}_{2}\right)_{86}\left(\mathrm{SiO}_{2}\right)_{106}\right] \cdot \mathrm{H}_{2} \mathrm{O}\right)$ and PVA (with an average molecular weight value of 89,000 to 98,000 and a 98 to $99 \%$ degree of hydrolysis) were supplied by Merck. The high purity analytical grade IPA used for this study was obtained from Sigma.

\section{Preparation of the PVA/NaY Membranes}

$\mathrm{NaY}$ zeolite at a concentration of $0.5 \%$ was added to the PVA solution $(2 \%)$, dissolved in distilled water at $85^{\circ} \mathrm{C}$ and mixed until the solutions were homogeneous. Different volumes of the freshly prepared solutions were poured into petri dishes and dried in an oven at $40^{\circ} \mathrm{C}$. The thickness of the membranes was measured with the aid of a digital micrometre (Dasqua 4210). All the membranes were thermally crosslinked at $150^{\circ} \mathrm{C}$ for 1 hour in the oven in order to prevent membrane solubility. The membranes were stored in a vacuum oven at $40^{\circ} \mathrm{C}$ until use.

\section{Characterization of the PVA/NaY Membranes}

In previous studies, the thermal behavior of the PVA and the PVA/NaY membranes was conducted using a SETERAM labSys thermogravimetric analyzer device over a temperature range from 0 to $900^{\circ} \mathrm{C}$ and a heating rate of $10^{\circ} \mathrm{C} / \mathrm{min}$ in an $\mathrm{N}_{2}$ atmosphere. The water contact angle of PVA and the PVA/NaY membranes were measured by an OCA50Micro contact angle meter (a Dataphysics contact angle measuring device). The morphology of the PVA and PVA/NaY membranes was investigated with scanning electron microscopy (SEM) (Hitachi SU3500). Images of the PVA and the PVA/NaY membranes were observed by atomic force microscopy (AFM) at room temperature and in an air atmosphere using the AFM tapping mode of a Veeco MultiMode V (Veeco Instruments, UK) (Kurşun, 2020).

\section{Evapomeation and TDEV Performance}

The PVA or PVA/NaY membranes were mounted onto the evapomeation or TDEV cell, put into a water bath with adjustable temperature. Evapomeation and TDEV experiments were performed for 1 hour under a low pressure of approximately 0.8 mbar (using an Edwards 12 vacuum pump) to pass IPA/water mixtures through the membrane using the apparatus used in a previous study (Kurşun, 2020). Throughout the evapomeation or TDEV experiments, the permeate removed through the membrane was collected in traps cooled with liquid nitrogen and weighed, and the IPA contents were detected by an Agilent Gas Chromatography (GS) device using calibration curves.

The flux value, $J$, was determined by weighing the permeate and then the separation factor $(\alpha)$, separation index (SI) and enrichment factor $(\beta)$ were calculated by the following four equations:

$$
\begin{aligned}
& J=\frac{W}{A . t} \\
& \alpha_{\text {Water } / \text { IPA }}=\left(\frac{P_{\text {Water }} / P_{I P A}}{V_{\text {Water }} / V_{I P A}}\right) \\
& \mathrm{SI}=\mathrm{J} . \alpha \\
& \beta=\frac{C_{\text {Water }_{P}}}{C_{\text {Water }_{F}}}
\end{aligned}
$$

where the mass of the permeate is $W$, the effective membrane area is $A(\mu \mathrm{m})$, the time is $t(\mathrm{~h}), V_{\text {Water }}$ and $V_{I P A}$ are weight fractions of the water and IPA vapours from the feed solution, and $P_{\text {Water }}$ and $P_{I P A}$ are weight fractions of the water and IPA in the permeate, respectively.

Here, $C_{\text {WaterP }}$ and $C_{\text {WaterF }}$ denote the concentration of water in the permeate and the feed solution, respectively. All experiments were performed in triplicate, and mean values were determined for the results.

\section{Results \\ The Effect of Feed Composition on Separation Factor and Flux in Evapomeation}

The effect of feed solution concentration on the separation factor and flux in the evapomeation method was investigated using a PVA/NaY membrane with a thickness of $50 \mathrm{um}$ at $35^{\circ} \mathrm{C}$ and is shown in Figure 1. It was observed that the separation factor decreased and the total and partial fluxes increased when the water percentage in the feed concentration was increased from $12.6 \%$ to $80 \%$. The best separation factor was calculated to be 1425.17 at the azeotropic point and the flux at this value was $28.32 \mathrm{~g} / \mathrm{m}^{2} \mathrm{~h}$.

When the results were examined, it was clear that the $\mathrm{PVA} / \mathrm{NaY}$ membrane was predominantly water permeable for aqueous IPA solutions. The degree of swelling of the PVA/NaY membrane in IPA/water solutions was measured to interpret the permeability and separation properties of the PVA/NaY membrane and is 
presented in Figure 2. The increase in flux values can be attributed to the increase in the amount of water in the feed solution - and thus in its vapour - the increased amount of water diffused into the membrane and greater swelling of the membrane. Since the passage of IPA molecules from the free volume formed by increased membrane swelling will be more, the separation factor decreases. In the evapomeation method, water and IPA monomolecules exhibited transition, since the vapour of the feed solution was in contact with the membrane. Therefore, dissolution or diffusion depended on the molecular size of the water and the IPA. Since water molecules with particle sizes smaller than IPA (water $0.296 \mathrm{~nm}$ and IPA $0.470 \mathrm{~nm}$ ) easily passed through the membrane matrix, the separation factor value decreased (Bowen, et al., 2004; Park et al., 2013). Similar results were reported in published literature (Kahya, et al., 2010). Kahya et al., 2010, separated dimethylformamide/water mixtures by the evapomeation method using sodium alginate/clinoptilolite composite membranes. They observed that with increased water concentration in the feed, the permeation rate increased, but the separation factor decreased.

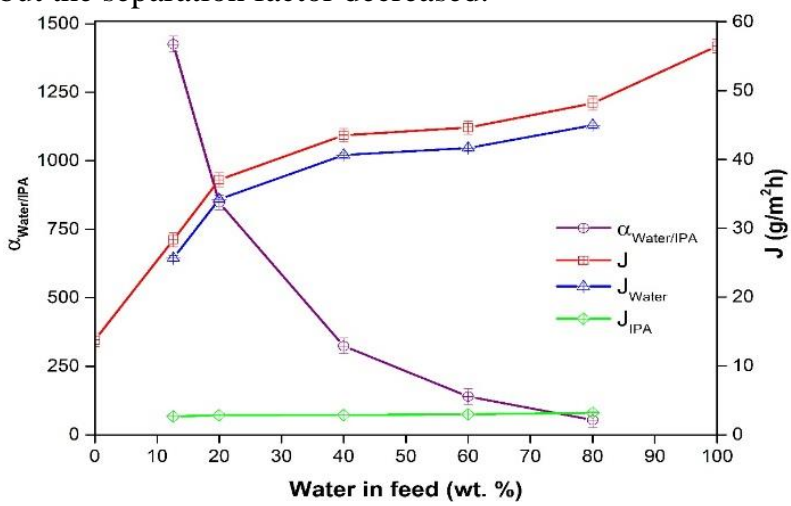

Figure 1. The effect of feed composition on separation factor and flux in evapomeation (NaY zeolite content: $0.5 \%$, membrane thickness: 50 $\mu \mathrm{m}$, feed solution temperature: $35^{\circ} \mathrm{C}$ )

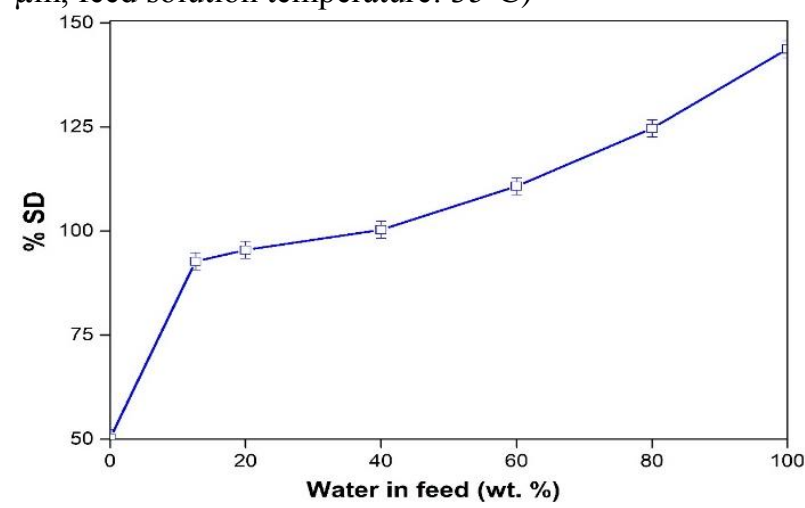

Figure 2. The effect of feed composition on swelling degree

The diffusion coefficients of water and IPA in PVA/NaY membrane were calculated with the help of the following equation and are shown in Table 1.

$$
J_{i}=-D_{i} \frac{d C_{i}}{d x}
$$

here, $J$ is defined as flux per unit area $\left(\mathrm{g} / \mathrm{m}^{2} \mathrm{~h}\right), D$ diffusion coefficient $\left(\mathrm{m}^{2} / \mathrm{s}\right), C$ permeate concentration $\left(\mathrm{g} / \mathrm{m}^{3}\right), x$ diffusion length $(\mathrm{m})$ and index $i$ water or IPA. Equality is simplified by assuming that the diffusion length is constant (Al-Ghezawi, et al., 2006):

$$
J_{i}=\frac{D_{i}}{\delta}\left[C_{i_{(f e e d)}}-C_{i_{(\text {permeate })}}\right]
$$

Here, $\delta$ stands for membrane thickness.

Table 1. Diffusion coefficients of water and IPA in $\mathrm{PVA} / \mathrm{NaY}$ membrane at different feed concentrations in evapomeation

\begin{tabular}{lll}
\hline Water (wt. \%) & $\mathrm{D}_{\text {Water. }} \cdot 10^{8}\left(\mathrm{~m}^{2} / \mathrm{s}\right)$ & $\mathrm{D}_{\text {IPA. }} \cdot 10^{8}\left(\mathrm{~m}^{2} / \mathrm{s}\right)$ \\
\hline 12.6 & 13.40 & 1.00 \\
20 & 18.54 & 1.18 \\
40 & 24.52 & 1.18 \\
60 & 42.49 & 3.36 \\
80 & 102.34 & 7.55 \\
\hline
\end{tabular}

When $D i$ values of water and IPA are compared, the fact that the $D i$ values of water are higher than the $D i$ values of IPA proved that the diffusion of water in the $\mathrm{PVA} / \mathrm{NaY}$ membrane is higher. The continuous increase in $D i$ values of water and IPA with an increased water percentage in the feed concentration can be attributed to the increased free volume in the membrane structure. The increased free volume in the membrane structure facilitated the diffusion of water molecules from the membrane. Figure 3, shows a steadily decreasing SI and $\beta$ change with an increase in water percentage in the feed solution from 12.6 to $80 \%$. Given this tendency, it is understood that at low water concentrations, especially at the azeotropic point, membrane separation factor is highest, and at these concentrations, separation by the evapomeation technique is more effective.

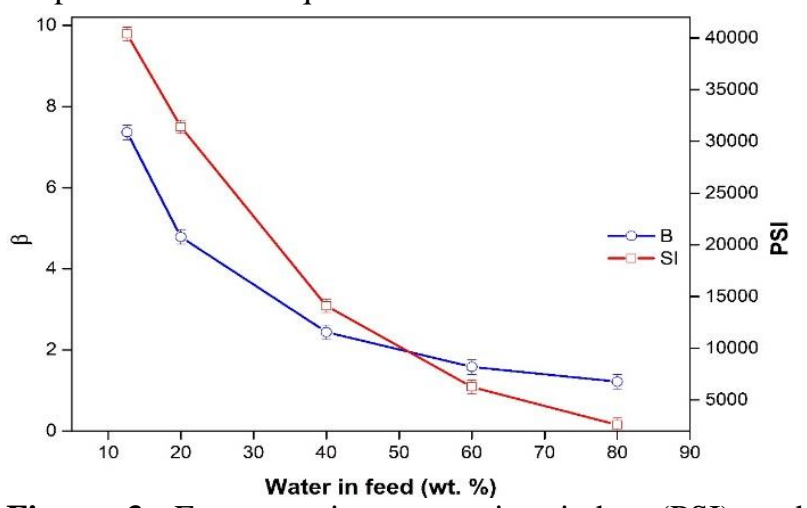

Figure 3. Evapomeation separation index (PSI) and enrichment factor $(\beta)$ results

(NaY zeolite content: $0.5 \%$, membrane thickness: 50 $\mu \mathrm{m}$, feed solution temperature: $35^{\circ} \mathrm{C}$ )

\section{The Effect of Temperature on Separation Factor and Flux in Evapomeation}

To investigate the effect of temperature on separation factor and flux, 87.4\% IPA/water mixtures were separated using a PVA/NaY membrane and changing the operating temperature from 20 to $40^{\circ} \mathrm{C}$, with the results 
presented in Figure 4. By increasing the working temperature from $20^{\circ} \mathrm{C}$ to $40^{\circ} \mathrm{C}$, it was observed that the separation factor values decreased and the total and partial flux values increased. The highest separation factor was calculated to be 2097.38 at $20^{\circ} \mathrm{C}$, and the flux at this value was $21.2 \mathrm{~g} / \mathrm{m}^{2} \mathrm{~h}$. With an increase in temperature, an increase was observed in the thermal mobility of the polymer chains and this increase led to the formation of free volume for the transfer of IPA/Water mixtures through the membrane. However, since the vapour pressure of IPA $\left(32.4 \mathrm{mmHg}\right.$ at $\left.20^{\circ} \mathrm{C}\right)$ is greater than the vapour pressure of water $\left(17.54 \mathrm{mmHg}\right.$ at $\left.20^{\circ} \mathrm{C}\right)$, the number of IPA molecules entering the vapour phase will increase with an increase in temperature (George and Barto, 1910; Petrucci, et al., 2010). With the effect of the increase in free volume and the vapour pressure difference, the separation factor values decreased and the flux values increased as the passage of IPA molecules through the membrane - along with the water molecules - was easier. The swelling studies in Figure 5 supported these results. Similarly, there are many studies in published literature where the flux increases and the separation factor decreases with an increase in temperature. Işıklan et al. tried to separate acetic acid/water mixtures from poly (vinyl alcohol)malic acid membranes using the evapomeation method. They reported that as the temperature increased from $30^{\circ} \mathrm{C}$ to $50^{\circ} \mathrm{C}$, the separation factor decreased and the flux increased. They found the highest separation factor was approximately 260 at $30^{\circ} \mathrm{C}$ (Işiklan and Şanli, 2005).

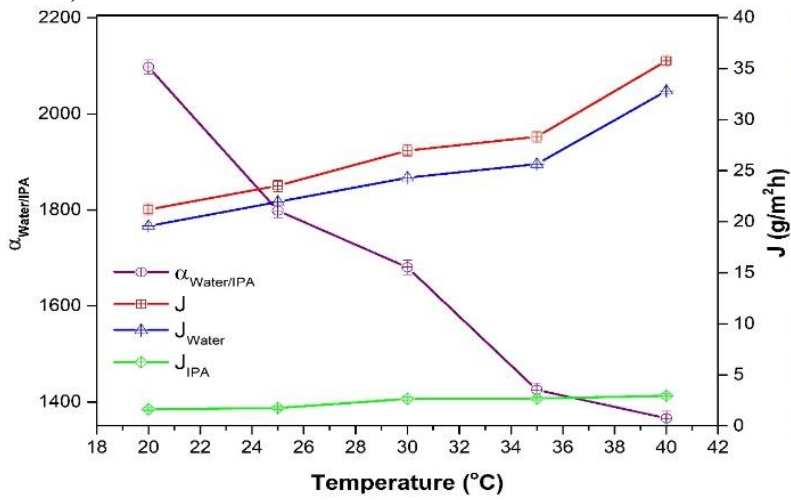

Figure 4. The Effect of Temperature on Separation Factor and Flux in Evapomeation

(IPA: $87.4 \%$, NaY zeolite content: $0.5 \%$, membrane thickness: $50 \mu \mathrm{m}$ )

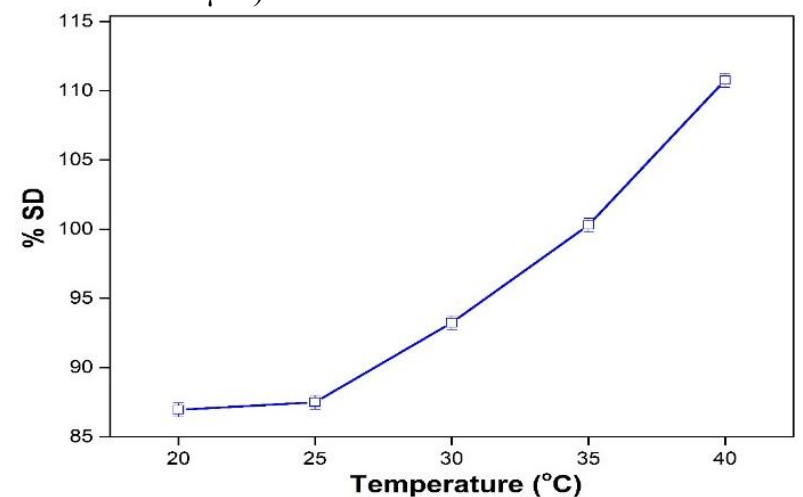

Figure 5. The effect of temperature on swelling degree (IPA: $87.4 \%$, NaY zeolite content: $0.5 \%$, membrane thickness: $50 \mu \mathrm{m}$ ).
The permeation and diffusion activation energies for IPA/water mixtures using the evapomeation method were calculated by plotting $\ln J$ and $\ln D$ versus $1 / \mathrm{T}$ plots, and the results are given in Table 2 .

Table 2. The permeation and diffusion activation energies

\begin{tabular}{ll} 
Activation Energies & $\mathrm{kj} / \mathrm{mol}$ \\
\hline $\mathrm{E}_{\mathrm{pWater}}$ & 23.36 \\
$\mathrm{E}_{\mathrm{pIPA}}$ & 36.64 \\
$\mathrm{E}_{\mathrm{p}}$ & 23.69 \\
$\mathrm{E}_{\mathrm{pIPA}}-\mathrm{E}_{\mathrm{pWater}}$ & 13.28 \\
$\mathrm{E}_{\mathrm{DW} \text { ater }}$ & 42,87 \\
$\mathrm{E}_{\mathrm{DIPA}}$ & 82.89 \\
$\mathrm{E}_{\mathrm{D}}$ & 41.61
\end{tabular}

When the permeation and diffusion activation energies of water and IPA are examined, it is seen that the permeation and diffusion activation energies of IPA are greater than the permeation and diffusion activation energies of water. This result can be attributed to the small size of the water molecule and its high polarity index. Also, the fact that the value of $\mathrm{Ep}_{\mathrm{IPA}}-\mathrm{Ep}_{\text {water }}$ was 13.28 meant that the passage of water molecules through the membrane will decrease as the temperature increases.

\section{The Effect of Feed Composition on Separation Factor and Flux in TDEV}

The TDEV process was carried out by using a PVA/NaY membrane. The membrane surrounding temperature was fixed at a temperature of $10^{\circ} \mathrm{C}$ while the feed solution to the TDEV cell was placed in a water bath at $20^{\circ} \mathrm{C}$. The results obtained by passing 0 to $100 \%$ IPA/water mixtures are given in Figure 6. It was observed that the separation factor decreased and the total and partial fluxes increased with an increase in water concentration in the feed solution.

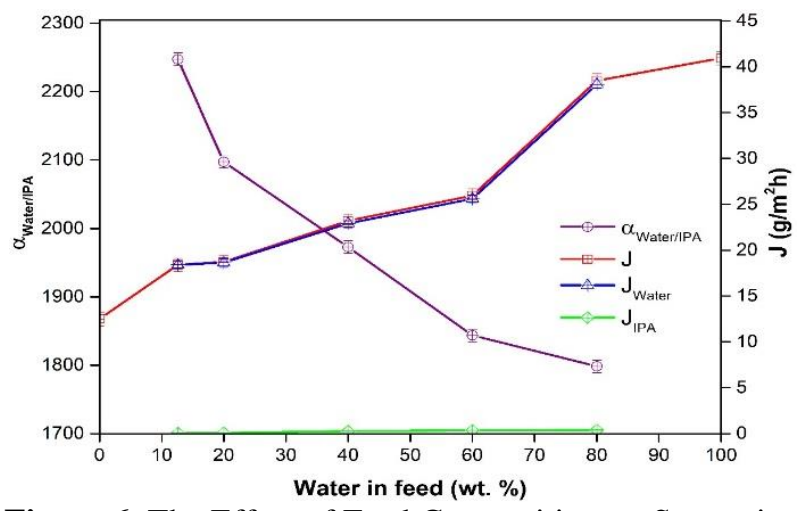

Figure 6. The Effect of Feed Composition on Separation Factor and Flux in TDEV

(NaY zeolite content: $0.5 \%$, membrane thickness: 50 $\mu \mathrm{m}$, feed solution temperature: $20^{\circ} \mathrm{C}$, membrane surrounding temperature: $10^{\circ} \mathrm{C}$ )

The best separation factor was calculated to be 2247.38 at the azeotropic point, and the corresponding flux value 
was $18.4 \mathrm{~g} / \mathrm{m}^{2} \mathrm{~h}$. The increase in flux values with the increased water percentage in the feed solution can be attributed to the increase in the amount of water passing through the membrane. The increased amount of water passing through the membrane can be attributed to the increase in the amount of water diffused into the membrane and the more selective behaviour of the membrane towards water as the amount of water in the feed solution vapour increased.

In Figure 7, it is understood that the membrane selectivity is highest at low water concentrations, especially at the azeotropic point, and separation by the TDEV technique is more effective at these concentrations. Işıklan et al. separated acetic acid/water mixtures by the TDEV method using poly (vinyl alcohol-g-itaconic acid) membranes. They reported that as the amount of acetic acid in the feed solution increased from $20 \%$ to $90 \%$, the separation factor value increased from 120.1 to 686 and the flux decreased from 0.354 to $0.144 \mathrm{~kg} / \mathrm{m}^{2} \mathrm{~h}$ (Işiklan \& Şanli, 2004).

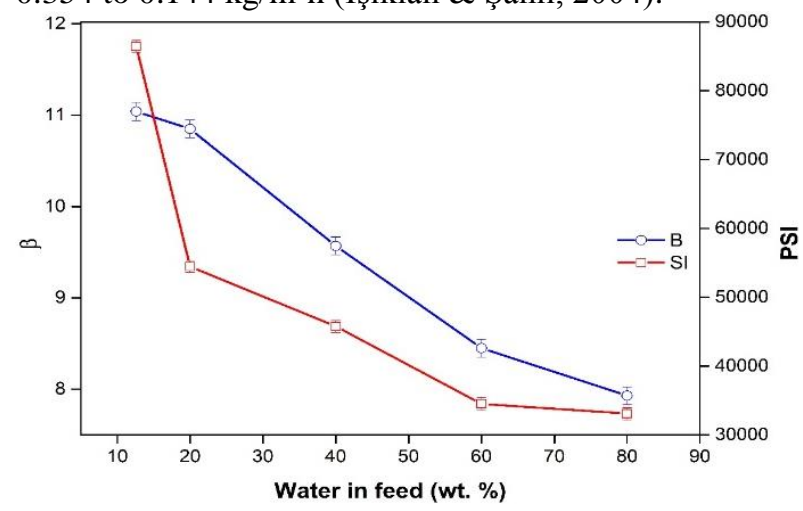

Figure 7. TDEV separation index (PSI) and enrichment factor $(\beta)$ results

(NaY zeolite content: $0.5 \%$, membrane thickness: 50 $\mu \mathrm{m}$, feed solution temperature: $20^{\circ} \mathrm{C}$, membrane surrounding temperature: $10^{\circ} \mathrm{C}$ )

\section{Effect of Temperature on Separation Factor and Flux in TDEV}

In the TDEV method, in order to examine the effect of membrane zone temperature on separation factor and flux, the temperature of the membrane zone was varied between 5 to $25^{\circ} \mathrm{C}$, the feeding solution was kept at $20^{\circ} \mathrm{C}$ and the $87.4 \%$ IPA/water mixtures were separated to give the results seen in Figure 8. The best separation factor was obtained when the membrane surrounding temperature was kept at $5^{\circ} \mathrm{C}$ with a value of 2483.75 . When the temperature was increased, the thermal mobility of the polymer chains increased. This increase led to the formation of free volume for the transfer of feed solution vapour across the membrane. Due to the increased free volume, along with the water vapour molecules, IPA vapour molecules also passed through the membrane. If the vapour pressure of IPA is about twice the vapour pressure of water, the amount of IPA passing into the vapour phase will increase and the amount of IPA passing through the membrane will increase. Therefore, with increasing temperature, flux values will increase as separation factor values decrease. Uragami et al. separated ethanol/water mixtures using the TDEV method using a poly (dimethylsiloxane) membrane. They reported that by increasing the temperature of the membrane zone from $-30^{\circ} \mathrm{C}$ to $30^{\circ} \mathrm{C}$, the separation factor decreased from 12 to 2 , while the flux increased from about 2 to $40 \mathrm{~g} / \mathrm{m}^{2} \mathrm{~h}$ (Uragami \& Morikawa, 1989).

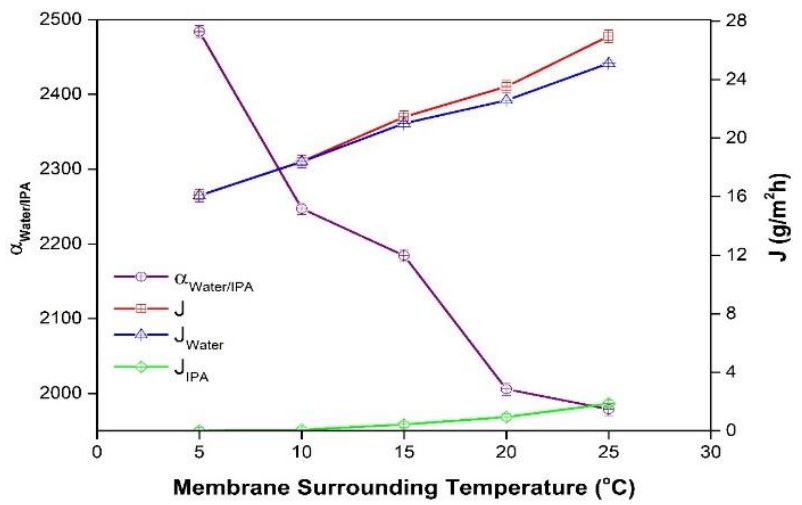

Figure 8. Effect of Temperature on Separation Factor and Flux in TDEV

(IPA: $87.4 \%, \mathrm{NaY}$ zeolite content: $0.5 \%$, membrane thickness: $50 \mu \mathrm{m}$, feed solution temperature: $20^{\circ} \mathrm{C}$ )

\section{Discussion and Conclusion}

In summary, the evapomeation and TDEV methods were used to separate IPA/water azeotropic mixtures. In both methods, it was observed that the separation factor decreased and the total and partial flux values increased with increasing water percentage in the feed concentration and with temperature. The best separation factor obtained was 2483.75 using the TDEV method with a PVA/NaY membrane $(0.5 \% \mathrm{NaY})$ for $87.4 \%$ IPA/water mixtures at a feed solution temperature of $20^{\circ} \mathrm{C}$ and a membrane surrounding temperature of $5^{\circ} \mathrm{C}$. In conclusion, using the evapomeation and TDEV methods, PVA/NaY membranes were found to be successful in the separation of IPA/water mixtures.

\section{Acknowledgements}

The author thanks Kurklareli University Research Foundation for its financial support (KLUBAP/204).

\section{Referances}

Al-Ghezawi, N., Şanli, O., Işiklan, N. (2006). Permeation and separation characteristics of acetic acid-water mixtures by pervapour ation through acrylonitrile and hydroxy ethyl methacrylate grafted poly(vinyl alcohol) membrane. Separation Science and Technology, 41(13), 2913-2931. doi.10.1080/01496390600786010

Ang, M. B. M. Y., Huang, S. H., Chang, M. W., Lai, C. L., Tsai, H. A., Hung, W. S., ... Lee, K. R. (2020). Ultraviolet-initiated graft polymerization of acrylic acid onto thin-film polyamide surface for improved ethanol dehydration performance of pervapour ation membranes. Separation and Purification Technology, 235(July 2019), 116155 doi.10.1016/ j.seppur.2019.116155

Asman, G., Şanli, O. (2006). Separation characteristics of acetic acid-water mixtures using poly(vinyl alcohol-g-4-vinyl pyridine) membranes by pervapour 
ation and temperature difference evapomeation techniques. Journal of Applied Polymer Science, 100(2), 1385-1394, doi.10.1002/app.23676

Bowen, T. C., Noble, R. D., Falconer, J. L. (2004). Fundamentals and applications of pervapour ation through zeolite membranes. Journal of Membrane Science, 245(1-2), 1-33, doi. 10.1016/ j.memsci.2004.06.059

Bui, T. D., Wong, Y., Thu, K., Oh, S. J., Kum Ja, M., Ng, K. C., ... Chua, K. J. (2017). Effect of hygroscopic materials on water vapour permeation and dehumidification performance of poly(vinyl alcohol) membranes. Journal of Applied Polymer Science, 134(17), 1-9, doi.10.1002/app.44765

Dmitrenko, M., Kuzminova, A., Zolotarev, A., Ermakov, S., Roizard, D., Penkova, A. (2020). Enhanced pervapour ation properties of PVA-based membranes modified with polyelectrolytes. application to IPA dehydration. Polymers, 12(1), 1-22, doi.10.3390/polym12010014

Fan, S., Wang, Y., Li, C., Lee, K., Liaw, D., Lai, J. (2003). Permselectivities of 2,2'-Dimethyl-4,4'bis(aminophenoxyl)- biphenyl Diphenyl MethaneBased Aromatic Polyamide Membranes for Aqueous Alcohol Mixtures in Pervapour ation and Evapomeation. Journal of Applied Polymer Science, 88, 2688-2697.

George, S. P., Barto, B. (1910). Vapour Pressure Data for Isopropyl Alcohol and Tertiary Butyl Alcohol. Contribution From The Chemistry Department of Stanford University, 50, 24-26.

Işiklan, N., Şanli, O. (2004). Permeation and separation characteristics of acetic acid/water mixtures through poly(vinyl alcohol-g-itaconic acid) membranes by pervapour ation, evapomeation, and temperaturedifference evapomeation. Journal of Applied Polymer Science, 93(5), 2322-2333, doi.10. 1002/app. 20710

Işiklan, N., Şanli, O. (2005). Permeation and separation characteristics of acetic acid-water mixtures through poly(vinyl alcohol)/malic acid membranes by evapomeation and temperature difference controlled evapomeation. Separation Science and Technology, 40(5), 1083-1101, doi. 10.1081/SS-200048179

Kahya, S., Solak, E. K., Şanli, O. (2010). Sodium alginate/poly(vinyl alcohol) alloy membranes for the pervapour ation, vapour permeation and vapour permeation with temperature difference separation of dimethylformamide/water mixtures: A comparative study. Vacuum, 84(9), 1092-1102, doi.10. 1016/j.vacuum.2010.01.033

Kurşun, F. (2020). Application of PVA-b-NaY zeolite mixture membranes in pervapour ation method. Journal of Molecular Structure, 1201, doi.10.1016/j.molstruc.2019.127170

Kwon, Y., Chaudhari, S., Kim, C., Son, D., Park, J., Moon, M., ... Nam, S. (2018). Ag-exchanged NaY zeolite introduced polyvinyl alcohol/polyacrylic acid mixed matrix membrane for pervapour ation separation of water/isopropanol mixture. RSC Advances, 8(37), 20669-20678, doi.10. 1039/c8ra03474e

Park, J. Y., Jung, H. C., Raju, G. S. R., Moon, B. K., Jeong, J. H., Choi, H. Y., Kim, J. H. (2013). Facile solvothermal synthesis and polarity based tunable morphologies of $\mathrm{ZnO}$ nanocrystals. Ceramics International, 39(6), 6599-6606, doi.10.1016/j.ceramint.2013.01.095

Petrucci, R.H., Harwood, W.S., Herring, F. G. (2010). Genel Kimya. (S. Uyar, T., Aksoy, Ed.). Ankara: Palme Yayıncılik.

Salehian, P., Chung, T. S. (2017). Two-dimensional (2D) particle coating on membranes for pervapour ation dehydration of isopropanol: A new approach to seal defects and enhance separation performance. Journal of Membrane Science, 544(June), 378-387, doi. 10.1016/j.memsci.2017.09.038

Uragami, T. (2017). Pervapour ation and Evapomeation with Si-Containing Polymers. In Membrane Materials for Gas and Vapour Separation (Vol. 10, pp. 335-372). John Wiley \& Sons, Ltd, doi. 10.1002/9781119112747.ch10

Uragami, T. (2018). Functional Separation Membranes From Grafted Biopolymers. Biopolymer Grafting: Synthesis and Properties. Elsevier Inc, doi.10.1016/B978-0-323-48104-5.00002-0

Uragami, T., Morikawa, T. (1989). Permeation of ethanol through poly(dimethylsiloxane) membranes using temperature differences in membrane permeation processes of the evapomeation method. Die Makromolekulare Chemie, Rapid Communications, 10(6), 287-291, doi. 10.1002/marc.1989.030100609. 